\title{
Susceptibility to Phytophthora ramorum and Inoculum Production Potential of Some Common Eastern Forest Understory Plant Species
}

\author{
Paul W. Tooley and Marsha Browning, USDA-ARS, Foreign Disease-Weed Science Research Unit, 1301 Ditto \\ Avenue, Ft. Detrick, MD 21702-5023
}

\begin{abstract}
Tooley, P. W., and Browning, M. 2009. Susceptibility to Phytophthora ramorum and inoculum production potential of some common Eastern forest understory plant species. Plant Dis. 93:249256.

Twenty-five plant species (21 genera, 14 families), which comprise a portion of the understory in forests of the Eastern United States, were evaluated for susceptibility to infection by Phytophthora ramorum. The degree to which $P$. ramorum is able to form sporangia and chlamydospores was also assessed on these hosts. Seedlings were spray-inoculated with a mixture $(4,000$ sporangia/ml) of four $P$. ramorum isolates followed by incubation in a dew chamber at $20^{\circ} \mathrm{C}$ in darkness for 5 days. Percent infection on individual leaves/leaflets was assessed visually. Mean percent leaf area infected ranged from $0.7 \%$ for Smilax rotundifolia to $93.8 \%$ for Kalmia latifolia. Eight plant species tested developed significantly larger lesion areas than those found on susceptible control Rhododendron 'Cunningham's White'. Fourteen species in addition to the susceptible control exhibited infection of over $90 \%$ of their leaves. Sporangia production by $P$. ramorum varied considerably among plant species, ranging from 36 per $\mathrm{cm}^{2}$ lesion area on Myrica pennsylvannica to 2,001 per $\mathrm{cm}^{2}$ lesion area on Robinia pseudoacacia. Numbers of chlamydospores produced per 6-mm-diameter leaf disk incubated in a $P$. ramorum sporangia suspension ranged from 25 on Ilex verticillata to 493 on Rhus typhina. The results indicate that many common understory species in Eastern U.S. forests are susceptible to P. ramorum and capable of providing ample sources of inoculum (sporangia and chlamydospores) for forest epidemics should the pathogen be introduced and should temperature and moisture conditions exist that are conducive to disease development.
\end{abstract}

Phytophthora ramorum is a destructive pathogen of oak and tanoak in California and Oregon $(10,31,33)$ and also causes disease symptoms on a large number of other plant species $(7,15)$. Quarantines have been in place since 2001 to prevent the spread of $P$. ramorum from infested areas $(1,28)$. A federal order went into effect on 10 January 2005 in response to detections of $P$. ramorum in California, Oregon, and Washington commercial nurseries and was replaced by an enhanced interim rule on 26 February 2006 (42). On 27 February 2007, restrictions were placed on the interstate movement of nursery stock in nonquarantined counties in California, Oregon, and Washington; interstate movement of all other nursery stock from quarantined areas was restricted; and the lists of regulated plants and quarantined areas were amended (29). The current list of $P$. ramorum hosts (43) includes 45 proven and 72 associated

Corresponding author: P. W. Tooley

E-mail: paul.tooley@ars.usda.gov

Accepted for publication 23 October 2008.

doi:10.1094/PDIS-93-3-0249

This article is in the public domain and not copyrightable. It may be freely reprinted with customary crediting of the source. The American Phytopathological Society, 2009. plant hosts, all of which are now subject to regulation.

The economic losses to growers associated with $P$. ramorum quarantine efforts have been high $(4,10)$. The likelihood that $P$. ramorum will one day become established in the Eastern United States keeps growing, due to the steady occurrence of positive $P$. ramorum finds in Eastern states that have suitable hosts and climate for disease development, and which receive plants from California, Oregon, and Washington $(2,10,38,46)$. Modeling has been performed to assess which areas of the Eastern United States are at highest risk of potential establishment of $P$. ramorum $(20,37,44)$.

Understory hosts susceptible to $P$. ramorum exist in California $(11,30)$ as well as Oregon forests $(12,14)$. However, there exist notable differences between California and Oregon in the epidemiological role played by California bay laurel, also known as Myrtlewood (Umbellularia californica) (13). California bay laurel is known to play a major role in driving epidemics in California forest ecosystems (5), whereas in Oregon, Myrtlewood is seldom infected (13). In both regions, foliar infection of various understory hosts is considered to serve as an important source of inoculum that may then be spread to oaks and tanoaks by various means such as rainsplash (6-8). Oaks originally were consid- ered to represent a "dead end" epidemiologically because no sporulation had been observed to occur on them $(30,33)$. However, Vettraino et al. (45) showed that $P$. ramorum was able to sporulate on coast live oak leaves, even though the role this phenomenon may play in the epidemiology of the disease may be far less that that played by the role of California bay laurel (8).

Several species native to other parts of the world have been screened for susceptibility to $P$. ramorum. An important Australian native species, Pittosporum undulatum, is susceptible to $P$. ramorum (16). Also, an assortment of Mediterranean shrubs were susceptible to $P$. ramorum (26). Eastern U.S. oak forest ecosystems are comprised of many understory species, in addition to mature oak species, that could potentially become infected by $P$. ramorum should it be introduced in an area where climate was suitable for infection and disease development. Several studies have been performed that have evaluated some Eastern U.S. native species for susceptibility to $P$. ramorum. Tooley et al. (40) screened a number of ericaceous host species that included the following Eastern U.S. native species or cultivars thereof: Arctostaphylos uva-ursi, Gaultheria procumbens, Gaylussacia baccata, G. frondosa, Kalmia angustifolia, K. latifolia, Leucothoe axillaris 'Greensprite', L. fontanesiana, Pieris floribunda, Rhododendron arborescens, $R$. calendulaceum, $R$. carolinianum, $R$. catawbiense, $R$. maximum, $R$. minus, $R$. vaseyi, $R$. viscosum, Vaccinium angustifolium, V. corymbosum, and Zenobia pulverulenta. A large variation in susceptibility of these native species was observed, measured both by lesion areas produced by $P$. ramorum and in terms of chlamydospore numbers produced in host tissue.

The susceptibility of seedlings of several oaks from the red and white oak groups including two Eastern U.S. native species, Quercus rubra (northern red oak) and $Q$. palustris (pin oak), was evaluated using stem inoculation with agar plugs of $P$. ramorum (32). Lesions in the bark of both species were longer than those developed in coast live oak (Q. agrifolia) and California black oak $(Q$. kellogii). Tooley and Kyde (39) also used stem inoculation to test seedlings of eight Eastern native oak species as well as sugar maple (Acer saccharum) and black walnut (Juglans nigra) 
and found all species to sustain stem lesions by $P$. ramorum, in some cases greater than those observed on the susceptible control, coast live oak. These workers also reported results of foliar inoculation of Eastern U.S. native oak species $Q$. prinus, $Q$. alba, $Q$. rubra, $Q$. pagoda, $Q$. laurifolia, and $Q$. virginiana. Linderman et al. (22) screened plants native to the U.S. Appalachian range using detached leaves, wounding plant tissue prior to inoculation, and inoculating using either sporangia or agar plugs containing mycelium of $P$. ramorum. These workers observed a wide range in susceptibility in these species, rated in terms of lesion area; however, sporulation of $P$. ramorum on the host species tested was not assessed.

Evaluation of susceptibility of additional understory species and sporulation capacity of $P$. ramorum on such species is merited to determine whether susceptible understory hosts may exist upon which abundant sporulation could occur that may fuel Eastern epidemics. Such information would aid in monitoring efforts $(37,41,46)$ so that inspectors may become aware of which species are most likely to sustain disease, and thus focus more attention on surveying those species. The information will also be important for pest risk assessment studies and modeling efforts $(3,20,23,24)$ designed to determine the potential threat posed by $P$. ramorum to
Eastern forest ecosystems. Thus, we evaluated the susceptibility of 25 plant species that are important members of the understory in Eastern U.S. forests, and also assessed the capacity of $P$. ramorum to produce sporangia and chlamydospores on these hosts.

\section{MATERIALS AND METHODS}

Selections of species commonly found in western Maryland hardwood forest understories (Table 1) were made based on species composition and abundance as presented by Yorks et al. (48). While understory species diversity is much broader across the range of high risk eastern hardwood forests (37), the selected species represent a sizable range of known host families and genera. Two susceptible controls were included in the experiments, Rhododendron 'Cunningham's White' and Syringa vulgaris, which are susceptible and support high numbers of $P$. ramorum sporangia $(36,40)$. Two- to 3 -year-old seedlings of most selected species were purchased commercially, whereas Acer rubrum, Rhus typhina, and Rubus allegheniensis were started from seed. A. rubrum when used were 6 to 8 months of age, $R$. typhina were 4 to 8 months of age, and $R$. allegheniensis were 5 to 9 months of age. Lonicera japonica, L. sempervirens, Rosa multiflora, Smilax rotundifolia, and Viburnum dentatum were propagated from foliar cuttings, and Sassafras albidium was propagated from root cuttings collected from wooded areas in York County, PA. We made the assumption that foliage from young seedlings grown from seed and tissue derived from cuttings are comparable with regard to $P$. ramorum sporangia production capacity, based on results with rhododendron (unpublished).

Four isolates of $P$. ramorum were utilized for inoculation: OR-03-74-1 (Clackamas Co., OR; Pieris japonica); Cam5C (Stanislaus Co., CA; Camilla sasanqua 'Bonanza'); WSDA 1741 (King Co., WA; Rhododendron 'Jean Marie'); and Pr-52 (Santa Cruz Co., Felton, CA; Rhododendron 'Gomer Waterer'). P. ramorum was cultured on $20 \%$ V8-juice agar medium (200 ml V8 juice, $2.4 \mathrm{~g} \mathrm{CaCO}_{3}, 20 \mathrm{~g}$ agar, $800 \mathrm{ml}$ distilled water). Sporangia were produced by incubating plugs removed from 10-day-old cultures in $1 \%$ sterile soil extract for $72 \mathrm{~h}$ at $20^{\circ} \mathrm{C}$. Sporangia from four isolates were combined and total concentration adjusted to 4,000 sporangia $/ \mathrm{ml}$. Plants were lightly misted with the sporangia suspension using a 480-ml-capacity industrial spray bottle (Lab Safety Supply, Janesville, WI) and then placed in dew chambers at $20^{\circ} \mathrm{C}$ in darkness. In each set of experiments, six plants from each of three species were inoculated along with several plants of Rhododendron 'Cunningham's White' that served as susceptible

Table 1. Foliar disease levels resulting from nonwounding spray-inoculation with combined inoculum of four isolates of Phytophthora ramorum

\begin{tabular}{|c|c|c|c|c|c|}
\hline Host & Common name & Family & Mean PLAI ${ }^{a}$ & Adj. mean PLAI ${ }^{b}$ & Mean PLIc \\
\hline Acer rubrum & Red maple & Aceraceae & 16.6 & 16.2 & 94.8 \\
\hline Amelanchier canadensis & Serviceberry & Rosaceae & 32.6 & 31.4 & 96.9 \\
\hline Asimina triloba & Pawpaw & Annonaceae & 8.4 & 8.1 & 94.2 \\
\hline Cercis canadensis ${ }^{\mathrm{d}}$ & Redbud & Fabaceae & 9.0 & 8.7 & 97.7 \\
\hline Cornus aтотит & Silky dogwood & Cornaceae & 7.6 & 4.6 & 25.6 \\
\hline C. florida & Flowering dogwood & Cornaceae & 71.1 & 70.4 & 99.1 \\
\hline C. racemosa & Grey dogwood & Cornaceae & 2.2 & 1.7 & 52.1 \\
\hline C. stolonifera & Red osier dogwood & Cornaceae & 6.9 & 6.8 & 97.3 \\
\hline Ilex verticillata & Winterberry & Aquifoliaceae & 23.6 & 21.7 & 86.1 \\
\hline Kalmia latifolia 'Hoffman's K' & Mountain laurel & Ericaceae & 93.8 & 93.8 & 100.0 \\
\hline K. latifolia 'Hoffman's Pink'd & Mountain laurel & Ericaceae & 92.0 & 92.0 & 100.0 \\
\hline Lindera benzoin & Spicebush & Lauraceae & 3.9 & 3.6 & 90.4 \\
\hline Lonicera japonica & Japanese honeysuckle & Caprifoliaceae & 1.4 & 0.4 & 21.9 \\
\hline L. sempervirens & Trumpet honeysuckle & Caprifoliaceae & 20.5 & 17.7 & 82.5 \\
\hline Myrica pennsylvannica & Bayberry & Myricaceae & 10.5 & 7.7 & 27.8 \\
\hline Prunus serotina & Black cherry & Rosaceae & 33.2 & 33.2 & 100.0 \\
\hline Rhododendron 'Cunningham's White' & Rhododendron & Ericaceae & 19.1 & 18.2 & 93.0 \\
\hline Rhus typhina & Staghorn sumac & Anacardiaceae & 31.2 & 30.8 & 96.8 \\
\hline Robinia pseudoacacia & Black locust & Fabaceae & 59.6 & 59.4 & 99.9 \\
\hline Rosa multiflora & Wild rose & Rosaceae & 45.8 & 39.6 & 84.3 \\
\hline Rubus allegheniensis & Common blackberry & Rosaceae & 5.0 & 1.1 & 1.2 \\
\hline Sambucus canadensis & Elderberry & Caprifoliaceae & 5.5 & 4.0 & 34.5 \\
\hline Sassafras albidium & Sassafras & Lauraceae & 56.5 & 56.5 & 100.0 \\
\hline Smilax rotundifolia & Green brier & Liliaceae & 0.7 & 0.2 & 20.0 \\
\hline Syringa vulgaris ${ }^{\mathrm{d}}$ & Common lilac & Oleaceae & 73.3 & 72.8 & 99.2 \\
\hline Viburnum dentatum & Arrowwood viburnum & Caprifoliaceae & 48.0 & 46.5 & 93.3 \\
\hline \multicolumn{3}{|c|}{ Tukey's minimum significant difference $(P=0.05)$} & 16.5 & 16.0 & 20.6 \\
\hline
\end{tabular}

a Mean percent leaf area infected. Six plants per species in each of 3 experiments were spray-inoculated with 4,000 sporangia/ml of a mixture of four $P$. ramorum isolates and incubated in dew chambers for 5 days at $20^{\circ} \mathrm{C}$. Two experiments only were performed with $\mathrm{K}$. latifolia species with 5 replicates and S. albidium with 3 replicates. Infected leaves were visually rated for percent disease.

${ }^{\mathrm{b}}$ Mean percent leaf area infected adjusted by percentage of leaves infected per plant in each experiment.

c Mean percent leaves infected (disease incidence).

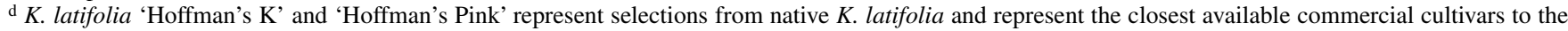
native type. Kalmia sp. and S. vulgaris are proven hosts regulated for P. ramorum by APHIS (43), while $C$. canadensis is considered by APHIS to be a host associated with $P$. ramorum. 
controls. Experiments were repeated until all species had been tested three times for a total of 18 plants per species, with a few exceptions due to limited availability of plants. Two experiments only were performed with $K$. latifolia 'Hoffman's Pink' and $K$. latifolia 'Hoffman's K' in replicates of 5, and two experiments with S. albidium in replicates of 3 due to limited availability. Following 5 days incubation in dew chambers, plants were removed and immediately rated for disease. Visual ratings of the percentage of each leaf (or leaflet for species with compound leaves) containing $P$. ramorum lesions were made with the assistance of a plant disease assessment key (17). Each leaf/leaflet was assigned a value for percent diseased leaf area. Several isolations from diseased leaf/leaflet tissue of each species were plated onto PARP selective medium (18) modified to contain $4 \%$ V8 juice, to confirm the presence of $P$. ramorum. The plants were then used to determine the potential for each species to support production of sporangia and chlamydospores by $P$. ramorum.

Sporangia production. Following 5 days dark incubation in dew, 3 plants per species were transferred to a mist chamber located in a climate-controlled greenhouse held at $20^{\circ} \mathrm{C}$. The leaves/leaflets on one branch per plant were positioned over a nitex mesh fabric (Sefar America, Inc., Depew, NY) screen with $15-\mu \mathrm{m}$ openings, which was supported by a cylinder cut from 8-in-diameter Schedule 40 PVC pipe. The fogging mist nozzles in the chamber were programmed to activate for $10 \mathrm{~s}$ every $4 \mathrm{~min}$. The mist produced was sufficient to keep the foliage moist and also to gently wash sporangia produced on the leaves onto the $15-\mu \mathrm{m}$ nitex mesh screens. With some species, diseased leaves dropped readily, so detached leaves/leaflets were positioned in screens with abaxial surfaces facing up. Dehisced sporangia were harvested from screens 3 times per week and washed into 50-ml centrifuge tubes. Most sporangia appeared intact and not empty or spent. The volume was raised to $30 \mathrm{ml}$ with distilled water, and the sporangia concentration in $3 / 500 \mu \mathrm{l}$ aliquots from each sample was determined. The sporangia suspension was transferred to 60 $\times 15 \mathrm{~mm}$ petri dishes placed atop a $3-\mathrm{mm}$ grid printed on an acetate sheet, and sporangia were counted at $\times 40$ magnification under dark field optics on a dissecting microscope. Following the 7-day harvest of sporangia, leaves were collected, scanned, and lesion area determined with ASSESS software (21). Data are the mean total number of sporangia produced in 7 days $/ \mathrm{cm}^{2}$ lesion area and also per leaf/leaflet.

Chlamydospore production. The number of chlamydospores produced in 6- $\mathrm{mm}$ leaf disks $\left(0.28 \mathrm{~cm}^{2}\right)$ was first evaluated in disks incubated in sporangia suspension. Leaf disks were removed from leaves that had first been surface-sterilized with $0.6 \%$ sodium hypochlorite. Twelve leaf disks per species were transferred to $60 \times 15 \mathrm{~mm}$ petri dishes. One $\mathrm{ml}$ of a 4,000 sporan$\mathrm{gia} / \mathrm{ml}$ suspension was added along with 3 $\mathrm{ml}$ of distilled water. Leaf disks were incubated in the sporangia suspension at $20^{\circ} \mathrm{C}$ for 10 days in darkness, at which time the liquid was replaced with distilled water and disks were left to incubate for another 20 days. Chlamydospores observed within the upper and lower leaf surfaces with a dissecting scope were counted. Three sets of 12 leaf disks were inoculated and assessed per species.

Three additional treatment regimes were employed for each set of inoculations to assess chlamydospore production on each host, for a total of three runs per plant species. Three plants from each pathogenicity screening were utilized in these chlamydospore evaluations. Leaf disks were removed from infected leaves following three different treatments: (i) 5 days dew, (ii) 5 days dew followed by 3 weeks in a greenhouse, and (iii) 5 days dew followed by 7 days in mist. For the first treatment (i), after 5 days in dew and completion of visual ratings for disease, 12 disks were removed from foliar lesions on each plant and transferred to glass vials containing $10 \mathrm{ml}$ of distilled water. Leaf disks were incubated for 3 weeks at $20^{\circ} \mathrm{C}$ and then fixed in 3 parts ethanol : 1 part glacial acetic acid (GAAE). For the second treatment (ii), following removal of leaf disks for the first chlamydospore evaluation, the same three plants were transferred to a greenhouse bench. Three weeks later, 12 leaf disks were removed from foliar lesions on each plant. Previously sampled leaves were removed from plants so that additional sampled disks came from previously unsampled leaves. When diseased leaf tissue was found to be dry and brittle, it was first rehydrated by soaking in distilled water for several hours prior to sampling. Leaf disks were then fixed with GAAE. For the third treatment (iii), 12 leaf disks were removed from diseased leaf tissue on those plants used for the determination of sporangia production (5 days in dew chambers followed by 7 days in a mist tent), transferred to vials, and fixed in GAAE.

After leaf disks had been collected and fixed, phenolic materials remaining in leaf disks were cleared by submersion in a 10:1 solution of $3 \%$ hydrogen peroxide and $20 \%$ ammonium hydroxide for up to $24 \mathrm{~h}$. Leaf disks were then transferred to a lactophenol solution to soften tissue. Twentyfour hours prior to examination, leaf disks were immersed in a cotton blue/lacto-

Table 2. Sporangia collected from leaves or leaflets infected by Phytophthora ramorum and positioned over nylon mesh screens in a mist chamber for 7 days $^{\mathrm{a}}$

\begin{tabular}{|c|c|c|c|}
\hline Host & $n^{\mathbf{b}}$ & $\begin{array}{l}\text { Sporangia per } \\
\mathrm{cm}^{2} \text { lesion area }\end{array}$ & $\begin{array}{l}\text { Sporangia per } \\
\text { leaf/leaflet }\end{array}$ \\
\hline Acer rubrum & 9 & 497.4 & 106.0 \\
\hline Amelanchier canadensis & 9 & $1,694.2$ & 148.4 \\
\hline Asimina triloba & 9 & 225.7 & 68.4 \\
\hline Cercis canadensis & 9 & 249.9 & 73.8 \\
\hline Cornus атотит & 9 & 125.9 & 27.2 \\
\hline C. florida & 9 & $1,594.2$ & 198.2 \\
\hline C. racemosa & 9 & 405.5 & 38.1 \\
\hline C. stolonifera & 9 & 92.9 & 85.4 \\
\hline Ilex verticillata & 9 & 54.3 & 79.0 \\
\hline Kalmia latifolia 'Hoffman's K' & 10 & 217.9 & 133.5 \\
\hline K. latifolia 'Hoffman's Pink' & 10 & 179.6 & 118.7 \\
\hline Lindera benzoin & 9 & 639.5 & 7.1 \\
\hline Lonicera japonica & 8 & $1,026.8$ & 6.1 \\
\hline L. sempervirens & 9 & 616.1 & 94.8 \\
\hline Myrica pennsylvannica & 9 & 36.3 & 78.8 \\
\hline Prunus serotina & 9 & 249.5 & 107.7 \\
\hline Rhododendron 'Cunningham's White' & 9 & 650.3 & 94.2 \\
\hline Rhus typhina & 9 & 824.4 & 50.0 \\
\hline Robinia pseudoacacia & 9 & $2,001.4$ & 125.8 \\
\hline Rosa multiflora & 9 & 928.2 & 57.9 \\
\hline Rubus allegheniensis & 1 & 191.2 & 2.5 \\
\hline Sambucus canadensis & 9 & 563.4 & 41.6 \\
\hline Sassafras albidium & 6 & $1,184.0$ & 164.2 \\
\hline Smilax rotundifolia & 7 & 573.1 & 8.0 \\
\hline Syringa vulgaris & 9 & $1,468.5$ & 160.3 \\
\hline Viburnum dentatum & 9 & 591.7 & 115.6 \\
\hline $\begin{array}{l}\text { Tukey's minimum significant difference } \\
(P=0.05)\end{array}$ & & $1,333.5$ & 88.6 \\
\hline
\end{tabular}

${ }^{a}$ One branch per plant was positioned over a $15-\mu \mathrm{m}$ nylon mesh screen under mist, and sporangia were harvested from screens 3 times over a 7-day period following a 5-day incubation in dew chambers at $20^{\circ} \mathrm{C}$, totaled, and counts were adjusted by diseased leaf area.

b Three plants were held under mist for sporangia collection following a 5-day incubation in dew chambers at $20^{\circ} \mathrm{C}$ in each of 3 experiments with the exception of $K$. latifolia ( 2 runs with 5 plants each) and S. albidium (2 runs with 3 plants each). With other species, when $n<9$ it is due to low infection levels by $P$. ramorum. 
phenol solution. Leaf disks were examined at $\times 200$ magnification using differential interference contrast optics, and the total number of chlamydospores in each leaf disk was counted. For each species, 12 leaf disks from each of three runs and three different time periods were evaluated for chlamydospore production. The epidermis was peeled off of leaf disks first softened in lactophenol to facilitate observations of chlamydospores in Kalmia species. The leaf disk sections were arranged on microscope slides with the interior section facing up. Chlamydospores were counted as described above.

Statistics. Analysis of variance (34) was used to analyze differences in infection levels and production of sporangia and chlamydospores among plant species. Means were compared using Tukey's studentized range test.

\section{RESULTS}

$P$. ramorum was isolated from foliar lesions on all species. Good foliar infection resulted on 'Cunningham's White' rhododendron (93\% of leaves infected, mean lesion area of $17.8 \mathrm{~cm}^{2}$ ) included in each dew chamber as a susceptible control. Eight species of plants tested developed significantly larger lesion areas than those found on Cunningham's White rhododendron (Table 1), and 14 species of plants (in addition to 'Cunningham's White' rhodo-
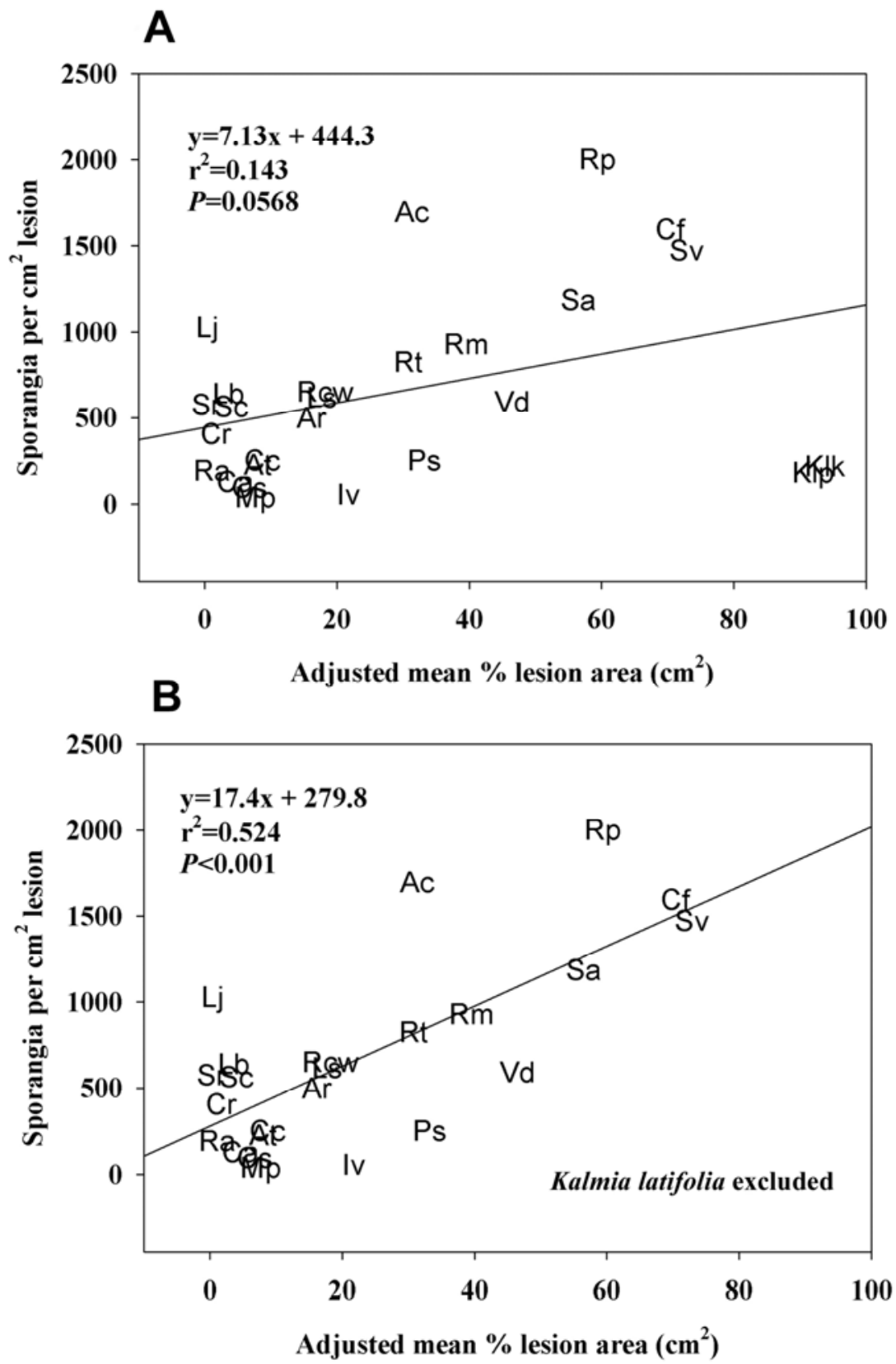

Fig. 1. Graphical representation of the relationship between mean lesion area (over all experiments) and sporangia production (mean total count over 7 days) for Eastern U.S. understory plant species inoculated with a mixture of four isolates of Phytophthora ramorum. Data points are indicated using an abbreviation for genus and species (see Table 1). A, Kalmia latifolia 'Hoffman's K' and 'Hoffman's Pink' included in analysis. B, K. latifolia 'Hoffman's K' and 'Hoffman's Pink' excluded from analysis. dendron) exhibited infection of over $90 \%$ of their leaves.

Sporangia production. Sporangia were produced by $P$. ramorum on all 25 species of plants tested during a 7-day incubation under mist. $P$. ramorum produced more sporangia per $\mathrm{cm}^{2}$ leaf area on Amelanchier canadensis, Cornus florida, and Robinia pseudoacacia than were produced on the susceptible control $S$. vulgaris. Species was a significant factor $(P<0.01)$ affecting spore production levels that ranged from a high of 2,001 sporangia $/ \mathrm{cm}^{2}$ lesion area produced by $P$. ramorum on $R$. pseudoacacia to a low of 36 sporangia $/ \mathrm{cm}^{2}$ produced on Myrica pennsylvannica (Table 2). Other species on which high levels of sporangia were produced relative to 'Cunningham's White' rhododendron included L. japonica, R. typhina, R. multiflora, and $S$. albidium. Regression analysis was used to examine the relationship between mean lesion area and sporangia production for the plant species evaluated. A linear relationship was observed $(P=$ $0.0568)$ with an $r^{2}$ value of 0.1431 when all species were included in the analysis (Fig. 1A). When the two K. latifolia genotypes were excluded from the analysis (Fig. 1B), a stronger linear relationship was observed $(P<0.001)$ with an $r^{2}$ value of 0.524 .

Chlamydospore production. For leaf disks removed from plants and incubated in a sporangia suspension for 10 days followed by distilled water for 20 days, significant differences among plant species were observed for chlamydospore counts from the upper and lower surfaces of leaf disks as well as for total counts $(P<0.01)$. Chlamydospores were produced within all species listed in Table 3; with $R$. typhina, Cercis canadensis, Cornus florida, S. albidium, and $R$. multiflora containing the largest quantity (493.6 to 388 per leaf disk $\left.\left[0.28 \mathrm{~cm}^{2}\right]\right)$. Chlamydospores could not be observed in K. latifolia incubated in sporangia suspension due to the thickness and dark coloration of the leaves, and attempts to count chlamydospores by sectioning the leaf disks were unsuccessful.

Chlamydospore levels in leaf disks were significantly affected by the treatment of plants $(P<0.01)$ prior to leaf disk harvest: (i) 5 days in dew chambers followed by 3 weeks in distilled water; (ii) 5 days in dew chambers followed by 7 days in a mist chamber; (iii) 5 days in dew followed by 3 weeks in a greenhouse. Significant effects were observed among plant species $(P<$ $0.01)$ and for the interaction of treatment and species $(P<0.01)$. When disease levels were low, sample sizes by necessity were less than 36 leaf disks (Table 4). Maximum chlamydospore production of 188 and $154 / 0.28 \mathrm{~cm}^{2}$ lesion area was observed on $S$. vulgaris and $R$. typhina, respectively, when disks were harvested from diseased tissue and incubated in distilled water for an additional 3 weeks. All 
species, with the exception of L. japonica, sustained some level of chlamydospore production by $P$. ramorum with this treatment.

When plants were transferred to a mist chamber for 7 days following 5 days in dew, chlamydospores were produced by $P$. ramorum on all species except Cornus amomum, L. japonica, $R$. pseudoacacia, and $S$. rotundifolia. There was insufficient diseased tissue to evaluate chlamydospore production in $R$. allegheniensis.

When plants were incubated for 3 weeks in a greenhouse following 5 days in dew chambers (Table 4), chlamydospore production was reduced compared to the other plant treatments, with the greatest quantity-14 spores/0.28 $\mathrm{cm}^{2}$ lesion areaproduced on $R$. typhina. Chlamydospores were not observed in disks harvested from A. canadensis, C. florida, C. racemosa, Ilex verticillata, L. japonica, Prunus serotina, S. albidium, Sambucus canadensis, or $S$. rotundifolia. Diseased leaf tissue of $R$. allegheniensis was not available for examination for chlamydospores due to low levels of disease. $R$. pseudoacacia sustained high levels of leaf abscission soon after inoculation, making it impractical to attempt to quantify chlamydospore production in plants held in a greenhouse. Diseased leaf tissue from $K$. latifolia was also unavailable since all plants were transferred to a mist chamber for sporangia collection.

\section{DISCUSSION}

We observed a wide range of susceptibility among the understory species tested. High levels of infection, as evidenced by lesion area, were observed in $P$. serotina and $R$. multiflora, but not in $R$. allegheniensis - another member of Rosaceae. In the family Lauraceae, of which California bay laurel (U. californica) is a member, $S$. albidium appeared to be moderately susceptible, with $56.5 \%$ leaf area infected, whereas Lindera benzoin exhibited little susceptibility (3.6\%). We also observed varying levels of disease establishment among species within a genus. C. florida was much more susceptible to infection by P. ramorum (70\% leaf area infected) compared to the other Cornus species tested (1 to $7 \%$ leaf area infected). Likewise, in the genus Lonicera, the native honeysuckle ( $L$. sempervirens) was susceptible to infection (17.7\% leaf area infected), whereas Japanese honeysuckle ( $L$. japonica) was relatively resistant $(0.4 \%$ leaf area infected $)$. Tubajika et al. (41) noted a large variation in disease incidence among genera and cultivars within a genus with regard to Camellia, Rhododendron, and Viburnum. In our study, plants commonly found along the forest edges, including $R$. pseudoacacia, $R$. typhina, and $S$. albidium, all displayed high levels of foliar infection, whereas L. japonica, R. allegheniensis, and $S$. rotundifolia were largely resistant. Al- though disease levels were low for Asimina triloba and $C$. canadensis, the high numbers of lesions observed (data not shown) suggest that an extended period of moisture may result in substantially higher levels of disease than reported here. Foliar infection of $R$. allegheniensis and S. rotundifolia could often be traced back to small wounds that occurred during transport and handling of plants. Therefore, disease levels reported here may overestimate the susceptibility of these plants to infection by $P$. ramorum. While the percent leaf area infected value was low for many of the plant species tested, it is worth noting that 18 out of the 25 plant species tested exhibited disease symptoms on $>80 \%$ of their leaves, demonstrating that $P$. ramorum is capable of infecting a wide range of plants commonly found in eastern forests.

Symptoms of disease on most species tested were discrete dark brown to black lesions, often coalescing to cover large areas of leaves, which are characteristic of infection by $P$. ramorum (7). On some species, including $S$. canadensis, C. amomum, C. racemosa, and $R$. multiflora, diseased leaf tissue appeared water-soaked. Upon removal from dew, these lesions quickly dried and shriveled. Infection was limited primarily to leaf tips in C. amomum and C. racemosa, and leaf tips and margins in $S$. canadensis as observed for California bay laurel and some other hosts (7). This may act in a way as to restrict petiole infection and leaf drop.

Table 3. Chlamydospore production by Phytophthora ramorum in leaf disks incubated in a sporangia suspension

\begin{tabular}{lrcc}
\hline & \multicolumn{3}{c}{ Mean number of chlamydospores per leaf disk $\mathbf{~}^{\mathbf{2}}$} \\
\cline { 2 - 4 } Host & Top & Bottom & Total \\
\hline Acer rubrum & 108.2 & 107.1 & 215.3 \\
Amelanchier canadensis & 194.7 & 71.9 & 266.6 \\
Asimina triloba & 220.6 & 5.2 & 225.8 \\
Cercis canadensis & 269.8 & 192.4 & 462.2 \\
Cornus amomum & 145.1 & 109.6 & 254.7 \\
C. florida & 335.5 & 120.7 & 456.2 \\
C. racemosa & 70.2 & 73.1 & 115.3 \\
C. stolonifera & 172.8 & 131.4 & 304.3 \\
Ilex verticillata & 24.3 & 0.4 & 24.8 \\
Lindera benzoin & 165.5 & 68.5 & 234.0 \\
Lonicera japonica & 70.2 & 3.9 & 74.1 \\
L. sempervirens & 120.2 & 21.9 & 120.2 \\
Myrica pennsylvannica & 105.5 & 31.3 & 136.8 \\
Prunus serotina & 65.7 & 26.7 & 92.4 \\
Rhododendron 'Cunningham's White' & 207.2 & 26.5 & 233.7 \\
Rhus typhina & 250.5 & 243.2 & 493.6 \\
Robinia pseudoacacia & 47.4 & 7.6 & 55.0 \\
Rosa multiflora & 272.7 & 206.5 & 388.4 \\
Rubus allegheniensis & 277.1 & 15.9 & 293.1 \\
Sambucus canadensis & 72.7 & 0.0 & 72.7 \\
Sassafras albidium & 335.1 & 92.8 & 425.8 \\
Smilax rotundifolia & 21.4 & 20.1 & 41.5 \\
Syringa vulgaris & 132.1 & 58.7 & 170.0 \\
Viburnum dentatum & 93.9 & 30.0 & 123.9 \\
Tukey's minimum significant difference & 84.8 & 53.8 & 117.9 \\
(P = 0.05) & & &
\end{tabular}

\footnotetext{
${ }^{a}$ Leaf disks $\left(6 \mathrm{~mm}\right.$ diameter, $\left.0.28 \mathrm{~cm}^{2}\right)$ were inoculated by placing in a suspension of $1,000 P$. ramorum sporangia for 10 days followed by 20 days incubation in distilled water at $20^{\circ} \mathrm{C}$. Data are means of 36 leaf disks ( 3 replications of 12 leaf disks). Chlamydospore counts in K. latifolia incubated in sporangia suspension were precluded by the thickness and dark coloration of the leaves.
} 
cally different from that produced by $P$. ramorum on $R$. pseudoacacia - the species that supported production of the highest number of sporangia. However, since disease levels were low and lesions small on L. japonica, sporangia production by $P$. ramorum on this species would be expected to be quite low. This illustrates the necessity for moderating predictions of sporangia production by expected infection levels (percent leaf area infected). C. flormore sporangia than did the other Cornus species tested and exhibited much higher levels of disease. While K. latifolia did not support production of copious amounts of $P$. ramorum sporangia, when one considers the high level of foliar infection (nearly $100 \%$ of leaf area diseased), there exists the potential for large numbers of sporangia to be produced on infected plants during a rain event. Numbers of sporangia produced per $\mathrm{cm}^{2}$ lesion on the understory hosts we tested are in agreement with those determined by Moralejo et al. (26) ida supported production of significantly

on detached leaves of Mediterranean plant species, which ranged from 0 to 552 .

Chlamydospore production was observed in all species evaluated when leaf tissue was incubated in a sporangia suspension, even in those species exhibiting low susceptibility to $P$. ramorum. For example, $R$. allegheniensis that had low levels of foliar infection produced a large number of chlamydospores, similar to that of $R$. multiflora. Chlamydospores were also produced in all plant species (with the exception of $L$. japonica) when diseased leaf tissue was removed from plants following 5 days in dew chambers and then incubated in water for 3 weeks. Twelve days incubation (5 days in dew followed by 7 days in mist) was sufficient for chlamydospores to be produced in 20 of 24 species tested. Chlamydospores were not evenly distributed throughout disks removed from diseased leaf tissue, so caution should be advised when estimating total chlamydospore production based on the number of chlamydospores observed in

Table 4. Chlamydospore production by Phytophthora ramorum in leaf disks removed from diseased foliar tissue

\begin{tabular}{|c|c|c|c|}
\hline \multirow[b]{2}{*}{ Host } & \multicolumn{3}{|c|}{ Chlamydospores/leaf disk ${ }^{a}$} \\
\hline & $\begin{array}{c}5 \text { days dew } \\
3 \text { wks water }\end{array}$ & $\begin{array}{l}5 \text { days dew } \\
7 \text { days mist }{ }^{\mathrm{c}}\end{array}$ & $\begin{array}{l}5 \text { days dew } \\
3 \text { wks gh }\end{array}$ \\
\hline Acer rubrum & 27.5 & 1.6 & 0.1 \\
\hline Amelanchier canadensis & 58.5 & 30.3 & 0.0 \\
\hline Asimina triloba & 68.3 & 9.0 & 1.3 \\
\hline Cercis canadensis & 55.2 & 13.4 & 6.5 \\
\hline Cornus атотит & 69.0 & 0.0 & 0.1 \\
\hline C. florida & 55.6 & 9.7 & 0.0 \\
\hline C. racemosa & 106.5 & 13.1 & 0.0 \\
\hline C. stolonifera & 25.9 & 10.8 & 0.4 \\
\hline Ilex verticillata & 90.0 & 55.1 & 0.0 \\
\hline Kalmia latifolia 'Hoffman's K' & $40.1(40)$ & $7.5(40)$ & $\ldots(0)$ \\
\hline K. latifolia 'Hoffman's Pink' & $17.2(40)$ & $13.8(40)$ & $\ldots(0)$ \\
\hline Lindera benzoin & 47.8 & 18.8 & 3.9 \\
\hline Lonicera japonica & $0.0(12)$ & $0.0(12)$ & $0.0(12)$ \\
\hline L. sempervirens & 114.0 & 25.1 & 3.8 \\
\hline Myrica pennsylvannica & 33.3 & 2.3 & 0.03 \\
\hline Prunus serotina & 67.7 & 67.4 & 0.0 \\
\hline Rhododendron 'Cunningham's White' & 94.6 & 40.1 & 0.8 \\
\hline Rhus typhina & 154.4 & 37.6 & 14.4 \\
\hline Robinia pseudoacacia & 10.3 & 0.0 & $\ldots(0)$ \\
\hline Rosa multiflora & 63.1 & 3.4 & 1.5 \\
\hline Rubus allegheniensis & $0.4(8)$ & $\ldots(0)$ & $\ldots(0)$ \\
\hline Sambucus canadensis & $0.1(7)$ & $1.4(27)$ & 0.0 \\
\hline Sassafras albidium & $115.7(24)$ & $17.3(24)$ & $0.0(24)$ \\
\hline Smilax rotundifolia & $10.3(28)$ & $0.0(12)$ & $0.0(12)$ \\
\hline Syringa vulgaris & 188.0 & 46.0 & 2.2 \\
\hline Viburnum dentatum & 51.2 & 31.6 & 1.9 \\
\hline $\begin{array}{l}\text { Tukey's minimum significant difference } \\
(P=0.05)\end{array}$ & 70.5 & 37.7 & 11.0 \\
\hline
\end{tabular}

a Plants were spray-inoculated with 4,000 sporangia/ml and incubated in dew chambers for 5 days at $20^{\circ} \mathrm{C}$. Data are means of 36 6-mm-diameter leaf disks (3 replications of 12 disks per experiment) unless disease levels were low ( $n$ noted in parentheses). Thus, the few existing lesions were used in the first two treatments. Some species also dropped their leaves in the greenhouse and could not be evaluated after 3 weeks. K. latifolia was not evaluated for the 5 days dew, 3 weeks greenhouse treatment because all plants were used in assessment of sporulation capacity.

${ }^{\mathrm{b}}$ Disks were removed from diseased leaf tissue following 5 days in dew chambers, placed in vials filled with distilled water, incubated for 3 weeks at $20^{\circ} \mathrm{C}$, and then fixed for microscopic observation.

${ }^{c}$ Plants were held under mist for 7 days following 5 days in dew chambers. Disks were removed from diseased leaf tissue and fixed for microscopic observation.

${ }^{\mathrm{d}}$ Plants were transferred to a greenhouse bench for 3 weeks following 5 days in dew chambers. Disks were removed from diseased leaf tissue, rehydrated when necessary, and fixed for microscopic observation. several subsamples. When plants were removed from dew chambers, foliar lesions often dried out and crinkled up within an hour or two, especially on younger leaves. It is likely that the rapid and extreme desiccation (induced by a reduction in relative humidity from $100 \%$ to 30 to $40 \%$ ) experienced by diseased leaf tissue upon removal from dew prevented or reduced the level of chlamydospore production in plants maintained in the greenhouse. Since we were unable to observe natural infections on these plants, we do not know if the severe drying of infected foliage we observed occurs in nature. Whether the propensity of diseased leaves to abscise in some species such as $R$. pseudoacacia and $R$. multiflora will reduce or eliminate the potential for spore production is also unknown. However, Shishkoff (35) demonstrated that segments of diseased $S$. vulgaris leaf tissue resting on the surface of potting medium produced inoculum that resulted in subsequent root infection. So, while moist conditions persist, detached leaves may continue to support production of sporangia and/or chlamydospores that have the potential to initiate new infections.

C. florida, R. pseudoacacia, S. albidium, $S$. vulgaris, and $V$. dentatum were found to be highly susceptible to $P$. ramorum, with all plants displaying a high percentage of leaves infected, large lesion areas, and high numbers of sporangia produced per $\mathrm{cm}^{2}$ lesion area. Linderman et al. (22) obtained detached leaf screening results for the following species that were also used in the present study: A. rubrum, C. amomum, $C$. florida, L. benzoin, $P$. serotina, $R$. typhina, and $S$. canadensis. Techniques differed in that leaves were wounded prior to inoculation, which may provide the pathogen with an artificial means of entry into host tissue. Also, they inoculated some leaves with mycelial plugs, which represents an unnatural form of inoculum. There were some discrepancies in results between the two studies, perhaps due to the different methods of inoculation used. Both studies found $C$. florida to be highly susceptible to $P$. ramorum, $P$. serotina moderately susceptible, and $A$. rubrum and C. amomum with low susceptibility. However, Linderman et al. (22) found with detached leaf studies that $L$. benzoin, $R$. typhina, and $S$. canadensis showed significantly higher levels of susceptibility than we observed in these species using whole plants. Detached leaf studies have been used by several additional workers to assess susceptibility of various hosts to $P$. ramorum $(9,14)$. Results of detached leaf studies should be interpreted carefully and checked against ratings obtained on whole plants, as higher susceptibility ratings in detached leaves could result because leaves have been removed from the plant and are under physiological stress when tested. Wounding prior to inoculation also may affect screening results. Kaminski and 
Wagner (19) observed significantly greater necrosis in wounded versus nonwounded tissue of three of the plant species they tested for susceptibility to $P$. ramorum.

Multiple factors must be considered when attempting to determine the overall susceptibility of a given species to $P$. ramorum. Both susceptibility, in terms of lesion areas produced on host tissue, and density of sporangia produced must be considered (25). Figure 1 shows the relationship between susceptibility (lesion size) and sporulation capacity of $P$. ramorum on the plant species we evaluated. It is clear that for some hosts, such as $K$. latifolia (mountain laurel), P. ramorum shows high virulence in terms of lesion area, but low sporulation capacity. This host is unusual in the very high amount of lesion tissue, leaf drop, and plant death sustained following inoculation with $P$. ramorum. For this reason, this host is considered to be one of the most susceptible species present in Eastern oak forests. Yet leaf drop and plant death following infection with $P$. ramorum would make this a less successful host overall in terms of supporting the pathogen than a species such as Japanese honeysuckle, which sustains much smaller lesions, but which supports profuse sporulation. Other hosts such as $C$. florida (flowering dogwood) and $S$. vulgaris (common lilac) show high susceptibility both in terms of lesion area and pathogen sporulation capacity. It may be that susceptibility in terms of lesion area could be a good measure for inspectors looking for first occurrences of $P$. ramorum in new areas, as these would be the species on which the pathogen would likely first be spotted. However, in terms of overall impact on the forest ecosystem, measures of overall sporulation as well as host density need to be taken into account for an adequate determination of the potential impact of $P$. ramorum to be made (20).

Davidson et al. (8) discussed the theory of Woolhouse et al. (47) that suggests that evolution of virulence on a certain host may be inversely related to the reproduction capacity on the host. Woolhouse et al. (47) discuss the trade-off between virulence and transmissibility for single-host versus multihost pathogens. They indicate that theory suggests no simple rule as to whether multihost pathogens will be more or less virulent than single-host pathogens. Our data support this suggestion, in that we found that the understory hosts we tested varied substantially in their ratios of pathogen virulence (lesion areas) to sporulation capacity. However, a significant linear response was observed between lesion area and sporulation capacity, indicating that hosts that sustained greater lesion areas also supported more profuse sporulation on a per unit area basis. When $K$. latifolia was excluded from the analysis due to its unusual leaf drop/plant death response, an even stronger linear response was observed $(P<0.001)$.

An additional epidemiological consideration resulting from our work is the finding that all the hosts tested supported chlamydospore production in varying amounts (Table 3). The role of chlamydospores in contributing inoculum to forest epidemics has not been clearly established. Thus, it is uncertain how much impact the ability to produce large numbers of chlamydospores in host tissue has on the overall contribution of a particular host species to additional epidemic cycles. However, our results do indicate that since all plant species tested allowed production of chlamydospores, all would have some chance of increasing pathogen survival under adverse environmental conditions.

We hope that our results will enhance efforts to monitor Eastern U.S. forests for the presence of $P$. ramorum should it be introduced $(27,37)$, assist in survey efforts by providing information about which species in a given region may be most susceptible and thus likely to show symptoms of $P$. ramorum, and be useful for predictive purposes as well. Some of the sporulation data from these studies have been used in recent risk mapping efforts (20) based on the distribution of the understory species in Eastern forests. The range of the host species included in such models must play an important part in such predictive efforts, as a host with low sporulation could still provide substantial amounts of inoculum to infect mature forest species if that host is widely distributed in a given forest ecosystem. Additional understory species should be examined in the future to determine levels of susceptibility both in terms of lesion areas and sporulation of $P$. ramorum, enabling them to be evaluated for their ability to play a part in potential epidemics of sudden oak death that may occur in Eastern forests.

\section{ACKNOWLEDGMENTS}

We thank Steve Dodge for excellent technical assistance in these studies.

\section{LITERATURE CITED}

1. California Department of Food and Agriculture. 2003. CDFA Plant Quarantine Manual, Section 301.92 Phytophthora ramorum. Pages 224.1-224.5.

2. California Oak Mortality Task Force. 2008. May newsletter. COMTF. Online. http://nature. berkeley.edu/comtf/html/newsletter_archive. html.

3. Cave, G. L., Randall-Schadel, B., and Redlin, S. C. 2005. Risk Analysis for Phytophthora ramorum Werres, deCock \& In't Veld, causal agent of Phytophthora canker (sudden oak death), ramorum leaf blight, and ramorum dieback. USDA-APHIS-PPQ Center for Plant Health Science and Technology, Plant Epidemiology and Risk Analysis Laboratory, Raleigh, NC.

4. Dart, N. L., and Chastagner, G. A. 2007. Estimated economic losses associated with the destruction of plants due to Phytophthora ramorum quarantine efforts in Washington State. Online. Plant Health Progress. doi: 10.1094/PHP-2007-0508-02-RS.
5. Davidson, J. M., Patterson, H. A., and Rizzo, D. M. 2008. Sources of inoculum for Phy tophthora ramorum in a redwood forest. Phytopathology 98:860-866.

6. Davidson, J. M., Rizzo, D. M., and Garbelotto, M. 2002. Phytophthora ramorum and sudden oak death in California: II. Pathogen transmission and survival. Pages 741-749 in: 5th Symposium on California Oak Woodlands. R Standiford and D. McCreary, eds. U.S. Dep. Agric. For. Serv., Gen. Tech Rep. PSW-GTR184.

7. Davidson, J. M., Werres, S., Garbelotto, M., Hansen, E. M., and Rizzo, D. M. 2003. Sudden oak death and associated diseases caused by Phytophthora ramorum. Online. Plant Health Progress. doi:10.1094/PHP-2003-0707-01-DG.

8. Davidson, J. M., Wickland, A. C., Patterson, H. A., Falk, K. R., and Rizzo, D. M. 2005. Transmission of Phytophthora ramorum in mixed-evergreen forest in California. Phytopathology 95:587-596.

9. Denman, S., Kirk, S. A., Brasier, C. M., and Webber, J. F. 2005. In vitro leaf inoculation studies as an indication of tree foliage susceptibility to Phytophthora ramorum in the UK. Plant Pathol. 54:512-521.

10. Frankel, S. J. 2008. Sudden oak death and Phytophthora ramorum in the USA: A management challenge. Australas. Plant Pathol. 37:19-25.

11. Garbelotto, M., Davidson, J. M., Ivors, K. Maloney, P. E., Huberli, D., Koike, S. T., and Rizzo, D. M. 2003. Non-oak native plants are main hosts for sudden oak death pathogen in California. Calif. Agric. 57:18-23.

12. Goheen, E. M., Hansen, E. M., Kanaskie, A. McWilliams, M. G., Osterbauer, N., and Sutton, W. 2002. Sudden oak death caused by Phytophthora ramorum in Oregon. Plant Dis. 86:441.

13. Hansen, E. M., Kanaskie, A., Goheen, E. M., Osterbauer, N., and Sutton, W. 2006. Epidemiology of Phytophthora ramorum in Oregon. Pages 27-29 in: Proceedings of the Sudden Oak Death 2nd Science Symposium: The State of Our Knowledge. S. J. Frankel, P. J. Shea and M. I. Haverty, tech coords. Gen Tech. Rep. PSW-GTR-196. Albany, CA. Pacific Southwest Res. Stn. For. Serv., U.S. Dep. Agric.

14. Hansen, E. M., Parke, J. L., and Sutton, W. 2005. Susceptibility of Oregon forest trees and shrubs to Phytophthora ramorum: A comparison of artificial inoculation and natural infection. Plant Dis. 89:63-70.

15. Henricot, B., and Prior, C. 2004. Phytophthora ramorum, the cause of sudden oak death or ramorum leaf blight and dieback. Mycologist 18:151-156.

16. Huberli, D., Wilkinson, C., Smith, M. A., Meshriy, M., Harnik, T. Y., and Garbelotto, M. 2006. Pittosporum undulatum is a potential Australian host of Phytophthora ramorum. Australas. Plant Dis. Notes 1:19-21.

17. James, C. 1971. A Manual of Assessment Keys for Plant Diseases. American Phytopathological Society, St. Paul, MN.

18. Jeffers, S. N., and Martin, S. B. 1986. Comparison of two media selective for Phy tophthora and Pythium species. Plant Dis. 70:1038-1043.

19. Kaminski, K., and Wagner, S. 2008. In vitro inoculation studies for estimating the susceptibility of ornamental plants to Phytophthora ramorum. J. Phytopathol. Online. doi: 10.1111/ j.1439-0434.2008.01399.x.

20. Koch, F. H., and Smith, W. D. 2008. Mapping sudden oak death risk nationally using host, climate, and pathways data. Pages 279-287 in: Proceedings of the Sudden Oak Death 3rd Science Symposium. S. J. Frankel, J. T. Kliejunas, and K. M. Palmieri, tech. coords. Gen. Tech. Rep. PSW-GTR-214. Albany, CA. U.S. Dep. Agric. For. Serv. Pacific Southwest Res. Stn. 
21. Lamari, L. 2002. ASSESS: Image Analysis Software for Plant Disease Quantification. American Phytopathological Society, St. Paul, MN.

22. Linderman, R. G., de Sa, P. B., and Davis, E. A. 2007. Comparative susceptibility of plants native to the Appalachian range of the United States to inoculation with Phytophthora ramorum. Plant Health Progress. Online. doi:10.1094/PHP-2007-0917-01-RS.

23. Magarey, R. D., Fowler, G. A., Borchert, D. M. Sutton, T. B., Colunga-Garcia, M., and Simpson, J. A. 2007. NAPPFAST: An internet system for the weather-based mapping of plant pathogens. Plant Dis. 91:336-345.

24. Magarey, R., Fowler, G., Colunga, M., Smith, W., and Meentemeyer, R. 2008. Climate-host mapping of Phytophthora ramorum, causal agent of sudden oak death. Pages 269-275 in: Proceedings of the Sudden Oak Death 3rd Science Symposium. S. J. Frankel, J. T. Kliejunas, and K. M. Palmieri, tech. coords. Gen. Tech. Rep. PSW-GTR-214. Albany, CA. U.S. Dep. Agric. For. Serv. Pacific Southwest Res. Stn.

25. Moralejo, E., Garcia Munoz, J. A., and Descals, E. 2006. Insights into Phytophthora ramorum sporulation: Epidemiological and evolutionary implications. EPPO Bull. 36:383388.

26. Moralejo, E., Puig, M., Garcia, J. A., and Descals, E. 2006. Stromata, sporangiomata, and chlamydosori of Phytophthora ramorum on inoculated Mediterranean woody plants. Mycol. Res. 110:1323-1332.

27. Oak, S. W., Smith, W. D., and Tkacz, B. M. 2006. Phytophthora ramorum detection surveys for forests in the United States. Pages 2830 in: Proceedings of the Third International IUFRO Working Party S07.02.09 Meeting Progress in Research on Phytophthora Diseases of Forest Trees. C. Brasier, T. Jung, and W. Osswald, eds. Forest Research Alice Holt Lodge, Farnham, Surry GU10 4LH, UK.

28. "Phytophthora ramorum." Code of Federal Regulations. 2003 ed. Title 7, Pt. 301.92. Pages 142-148.

29. "Phytophthora ramorum." Quarantine and
Regulations. 2007. Federal Register 72(38): 8585-8604. 7 CFR part 301

30. Rizzo, D. M. 2003. Sudden Oak Death: Host plants in forest ecosystems in California and Oregon. Sudden Oak Death Online Symposium. doi: 10.1094/SOD-2003-DR.

31. Rizzo, D. M., Garbelotto, M., Davidson, J. M., Slaughter, G. W., and Koike, S. T. 2002. Phytophthora ramorum as the cause of extensive mortality of Quercus spp. and Lithocarpus densiflorus in California. Plant Dis. 86:205-214.

32. Rizzo, D. M., Garbelotto, M., Davidson, J. M., Slaughter, G., and Koike, S. T. 2002. Phytophthora ramorum and sudden oak death in California: I. Host Relationships. U.S. Dep. Agric. For. Serv. Gen. Tech. Rep. PSW-GTR184.

33. Rizzo, D. M., Garbelotto, M., and Hansen, E. M. 2005. Phytophthora ramorum: Integrative research and management of an emerging pathogen in California and Oregon forests. Annu. Rev. Phytopathol. 43:309-335.

34. SAS Institute Inc. 2004. SAS/STAT 9.1 User's Guide. SAS, Cary, NC.

35. Shishkoff, N. 2006. Behavior of lilac leaves infected with Phytophthora ramorum when placed on the surface of nursery pots. (Abstr.) Phytopathology 96:S107.

36. Shishkoff, N. 2007. Susceptibility of some lilac cultivars and other members of the Oleaceae to Phytophthora ramorum. Plant Health Progress. doi: 10.1094/PHP-20071101-02-RS.

37. Smith, W. D., Couston, J. W., Goheen, E. M., Sapio, F., Gottschalk, K. W., Frankel, S. J., Dunn, P., and Tkacz, B. M. 2002. Development of a national survey protocol for detection of Phytophthora ramorum. Proceedings of the Sudden Oak Death Science Symposium.

38. Stokstad, E. 2004. Nurseries may have shipped sudden oak death pathogen nationwide. Science 303:1959.

39. Tooley, P. W., and Kyde, K. L. 2007. Susceptibility of some Eastern forest species to Phytophthora ramorum. Plant Dis. 91:435-438.

40. Tooley, P. W., Kyde, K. L., and Englander, L. 2004. Susceptibility of selected ericaceous or- namental host species to Phytophthora ramorum. Plant Dis. 88:993-999.

41. Tubajika, K. M., Bulluck, R., Shiel, P. J., Scott, S. E., and Sawyer, A. J. 2006. The occurrence of Phytophthora ramorum in nursery stock in California, Oregon, and Washington states. Plant Health Progress. doi: 10.1094/PHP2006-0315-02-RS.

42. USDA-APHIS. 2008. Plant health: Phy tophthora ramorum/sudden oak death. U.S Dep. Agric. Animal and Plant Health Inspection Service-Plant Protection and QuarantineEmergency and Domestic Programs. (http:// www.aphis.usda.gov/plant_health/plant_pest_ info/pram/index.shtml)

43. USDA-APHIS. 2008. APHIS list of regulated hosts and plants associated with Phytophthora ramorum, revised 5 May 2008. Online. Plant Pest Prog. Info., Pest List. U.S. Dep. Agric., Washington, DC.

44. Venette, R. C., and Cohen, S. D. 2006. Potential climatic suitability for establishment of Phytophthora ramorum within the contiguous United States. For. Ecol. Manage. 231:18-26.

45. Vettraino, A. M., Huberli, D., and Garbelotto, M. 2008. Phytophthora ramorum infection of coast live oak leaves in Californian forests and its capacity to sporulate in vitro. Australas. Plant Pathol. 37:72-73.

46. Wamishe, Y. A., Jeffers, S. N., and Hwang, J. 2008. Monitoring for Phytophthora ramorum and other species of Phytophthora in nurseries and urban areas of the Southeastern USA. Pages 109-110 in: Proceedings of the sudden oak death third science symposium. Gen. Tech. Rep. PSW-GTR-214. S. J. Frankel, J. T. Kliejunas, and K. M. Palmieri, tech. coords. Albany, CA. U.S. Dep. Agric., For. Serv., Pacific Southwest Res. Stn.

47. Woolhouse, M. E. J., Taylor, L. H., and Haydon, D. T. 2001. Population biology of multihost pathogens. Science 292:1109-1112.

48. Yorks, T. E., Dabydeen, S., and Smallidge, P. J. 2000. Understory vegetation-environment relationships in clearcut and mature secondary forests of Western Maryland. Northeastern Naturalist 7:205-220. 